ДО ПИТАННЯ ПРО ТРАСГЕНЕРАЦИЙНУ ПЕРЕДАЧУ КОЛЕКТИВНОЇ ТРАВМИ У ПРЕДСТАВНИКІВ УКРАЇНСЬКОГО ЕТНОСУ

\title{
ON THE ISSUE OF TRANSGENERATIONAL TRANSMISSION OF COLLECTIVE TRAUMA IN THE UKRAINIAN ETHNIC GROUP
}

Стаття присвячена висвітленню результатів наукових досліджень щодо френомену трансгенераційної передачі травми з огляду на чинну ситуацію в Україні. Стаття має на меті аналіз особливостей трансгенераційної передачі травми в рамках представників українського етносу, пошук потенційно вирішальних кроків на шляху до зменшення прояву трансгенераційної передачі у наступних поколіннях. Вживання терміна «етнос», а не «нація» зумовлене тим, що колективна травма також може охоплювати людей, які особисто не зіштовхнулися 3 травматичною подією, однак їхні предки були її свідками. Відомо, що серед найбільш травмогенних фракторів для представників українського етносу були такі: Велика вітчизняна війна, екологічні катастрофи, Чорнобильська катастрофа, колективізація, репресії 30-40-х років, геноцид та Голодомор. Аналіз наукових досліджень показав, що серед найбільш деструктивних наслідків даних подій для наступних поколінь можна виділити амбівалентність почуттів, відчуття провини та сорому, пошук «героїчного рішення», відчуття страху та безпорадності, жагу до помсти та самоінсрляцію. у нашому дослідженні травма розглядається крізь призму ії походження (біологічно-демографрічна, соціально-політична, культурна), а також крізь призму рівнів впливу (індивідуальний, колективний, культурний). Подальшу наукову роботу доцільно зосередити на емпіричних дослідженнях Революції гідності та анексії Криму. Дисонанс між історичними злочинами та необхідністю підтримувати позитивний імідж етносу може бути вирішений. До цього може спонукати створення нового групового наративу, який визнає травму і використовує ї̈ як фоон, щоб підкреслити поточну позитивну динаміку. Для цього необхідно виокремити вплив ключових травмуючих подій на покоління, які безпосередньо зіткнулися з ними, та проаналізувати потенційний вплив цих подій на наступні покоління.

Ключові слова: трансгенераційна передача, колективна травма, історична травма, терапія травми, українська ідентичність.

This article is devoted to the coverage of the results of scientific research on the phenomenon of transgenerational transmission of trauma in view of the current situation in Ukraine. This article aims to analyze the features of transgenerational transmission of trauma within the Ukrainian ethnic group; search for potentially decisive steps towards reducing the phenomenon of transgenerational transmission in future generations. The use of the term "ethnicity" rather than "nation" is due to the fact that collective trauma can also involve people who have not personally experienced a traumatic event, but whose ancestors have witnessed it. It is known that among the most traumatic factors for the Ukrainian ethnic group were the following: the Second World War, environmental disasters, the Chernobyl disaster, collectivization, repression of the 30-40s, genocide and the Holodomor. Analysis of scientific research has shown that among the most destructive consequences of these events for future generations are ambivalence of feelings, feelings of guilt and shame, the search for a "heroic solution", feelings of fear and helplessness, desire for revenge and self-inflation. In this study, trauma is considered through the prism of the nature of its origin: biological and demographic; sociopolitical; cultural and levels of influence: individual; collective; cultural. Further research in this direction is seen in the empirical studies of the Revolution of Dignity and annexation. The dissonance between historical crimes and the need to maintain a positive image of the ethnic group can be resolved. This can be prompted by the creation of a new group narrative that recognizes the trauma and uses it as a background to emphasize the current positive dynamics. To do this, it is necessary to identify the impact of key traumatic events on the generations that directly faced them and analyze the potential impact on future generations. Key words: transgenerational transmission, collective trauma, historical trauma, trauma therapy, Ukrainian identity.

Харківський національний університе внутрішніх справ

Проблема колективної травми для представників українського етносу $€$ значущою, адже нові травматичні події накладаються на невідрефлексовані травми минулого. В історичному розрізі досвід України $є$ сумним з огляду на війни, репресії та геноциди, що мали місце на нашій території. У зв'язку із цим виникає потреба в аналізі потенційного впливу травмуючих подій на наступні покоління з метою превенції повторення негативного досвіду та подальшої інтеграції травми в культурний наратив країни.

Хоча спочатку 3. Фрейд стверджував, що перенесена і пригнічена травма викликає невротичні симптоми, пізніше він поставив під сумнівце твердження та визнав важливість теорії несвідомих конфліктів і поставив динаміку несвідомих бажань і фантазій у центр подальших теорій. Внаслідок цього в психоаналізі з'явилась незліченна кількість робіт і визначень терміна «травма». Лаконічне визначення надають Г. Фішер та Л. Рідессер [1, с. 145-147], які визначають психологічну травму як «життєвий досвід невідповідності між загрозливими ситуаційними факторами та індивідуальними можливостями подолання, який супроводжується відчуттям безпорадності й, отже, є постійним 
шоком, що негативно впливає на впевненість у собі та сприйняття світу». На думку авторів, травма виникає в життєвій ситуації, яка зводить нанівець правила нормальної обробки досвіду. Існують зміни в сприйнятті часу, простору і «Я» (рецепторна сфера). Оглядаючи ретроспективу, ті, хто страждає від травми, описують переживання повного поглинання та захоплення ситуацією, деперсоналізації («стояти поруч із собою»), дереалізації («це нереально, це як уві сні») або забуття вирішальних подій. У психоаналізі боротьба з психологічними травмами, викликаними зовнішніми факторами, такими як політичне та соціальне насильство, довгий час мала другорядне значення: Голокост, бомбардування, депортації, втечі та переслідування, а також проблеми насильства в сім'ях почали переосмислювати з 1980-х років [2, с. 48].

Колективна травма - це катаклізм, який руйнує основну тканину суспільства. Окрім жахливої втрати людських життів, колективна травма також $є$ кризою сенсу. Термін «колективна травма» стосується психологічних реакцій на травматичну подію, які впливають на все суспільство. Колективна травма не просто зображає історичний факт, спогад про страшну подію, яка сталася з групою людей, в свідчить про те, що трагедія, представлена в колективній пам'яті групи людей, містить в собі потребу не лише у відтворенні подій, а й у постійному реконструюванні травми під час її осмислення. Колективна пам'ять про травму відрізняється від індивідуальної, оскільки колективна пам'ять зберігається за межами життя тих, хто пережив події. Травматичні події пам'ятають ті члени групи, які можуть бути далекими від травматичних подій у часі та просторі. Наступні покоління, тобто нащадки постраждалих від травм, які ніколи не були свідками реальних подій, можуть пам'ятати події інакше, ніж ті, хто їх пережив. у такому разі конструкція цих минулих подій може мати різну форму від покоління до покоління [3, с. 38].

Що стосується трансгенераційної передачі травми, то існує два основних питання: 1) як ті, що вижили, можуть несвідомо передати травмогенні переживання своїм нащадкам; 2) як ці переживання відтворюються, інтерпретуються або реконструюються під час терапії другого і третього покоління. В. Гампел та І. Коган вважають, що батьки несвідомо експлуатують своїх дітей за допомогою процесу проєктивної ідентифікації, щоб стримувати жалобу та агресію, які вони мали б відчувати самі і які могли б бути саморуйнівними [4, с. 148-150]. Це уявлення узгоджується з ідеєю І. ГрубрихаСімітиса про конкретизацію та невдачу символізації [5, с. 301-309]. Оскільки батьки в першому поколінні не можуть знайти ні метафор, ні символічного способу, щоб висловити або передати те, що з ними сталося, їхній досвід стає для дитини чи онука свого роду конкретною промовою, яку не можна обговорювати. Подібним чином Х. Файмберг [6, с. 23-27] говорить про телескопію поколінь, а В. Волкан [7, с. 13-15] говорить про передачу групового досвіду, тобто фантазій про те, що сталося з усією соціальною групою.

Серед найбільш впливових травматичних подій, що мали місце в історії України, можна виділити такі: Перша світова війна, Громадянська війна, колективізація і депортації, Голодомор, Великий терор, Велика вітчизняна війна, Голодомор, Чорнобильська катастрофа, Революція гідності. За своєю природою дані травми можна віднести до трьох типів травм (за класифікацією П. Штомпки): біологічно-демографічні, соціально-політичні, культурні. Відомо, що характер впливу травматичної події варіюється залежно від її типу, тому об'єкт трансгенераційної передачі (відчуття, установки та поведінкові механізми) також буде відрізнятися [8, с. 450-453].

Необхідно зазначити, що навіть в рамках одного типу травми механізми копінгу в різних етносах будуть варіюватися, бо даний феномен володіє більшою комплексністю через попередній соціальний, культурний, політичний досвід поколінь.

Для нащадків поколінь, що зазнали травмування, важливо відрізняти почуття сорому від почуття провини, особливо від почуття провини людини, яка вижила. Почуття провини-цеоб'єктнепочуття, пов'язаневиключноз «Я-образом» або почуттям ідентичності. У людей з почуттям провини акцент зосереджується на почуттях і думках тих, хто вижив (пізніше й у їхніх дітей), що вони залишилися живими, тоді як інші, можливо, більш гідні, ніж вони самі, були вбиті. Їхнє життя нерозривно пов'язане зі смертю інших. Люди, які пережили цю травму, можуть також відчувати, що вони не змогли врятувати життя тих, хто був їм близький і дорогий.

Від цієї провини не можна легко позбавитися, просто вказавши на те, що вона несумірна з тим, що «втікачі» самі були змушені страждати, але її можна пом'якшити через жалобу та скорботу.

Скорбота - це пропрацювання всіх суперечливих емоцій, пов'язаних із втраченим об'єктом і втраченими стосунками, а також процес відновлення єдності, «з'єднання різних членів роз'єднаного тіла». Отже, це відчуття пов'язане з репарацією, змогою якимось чином виправити те, що було пошкоджене або знищене. У цьому контексті Б. Варді визначає конкретних членів сім'ї у другому поколінні як «свічки пам'яті». Це ті діти, які прагнуть відшкодувати збитки, читати про Голокост, пам'я- 
тати про нього, можливо, писати про нього, тоді як їхні брати й сестри часто заохочують суперечки, в яких вони апелюють до майбутнього, яке не має нічого спільного з травмою. Герман Гессе зазначав: «Поряд з потребою пам'ятати у людства немає більшого голоду, ніж забути». У сім'ях, які вижили, обидві ці тенденції часто присутні в екстремальних проявах [9, с. 4-7].

Сором, оскільки він більше пов'язаний із суб'єктом, ніж з об'єктом, часто важче подолати, ніж провину, оскільки немає нікого, на кому можна було б вимістити заподіяну шкоду. Сором пов'язаний з тим, як ми бачимо себе, та з тим, як нас можуть бачити інші. Він може бути так само нищівним, як і почуття провини, але сором існує без жодної можливості оплакати чи відшкодувати, виправити те, що було пошкоджене чи знищене. Як стверджував А. Когут [10, с. 472-475], самоінфляція є одним з основних і необхідних примітивних засобів захисту від почуття дитячої безпорадності та дестабілізації образу «Я».

Друге та третє покоління після Голокосту, безумовно, повинні бути обережними, демонструючи своє почуття нестабільності, розколу ідентичності, хворобливу спадщину травмування їхніх сімей у суспільному чи соціальному контексті. Проте, здається, вони також можуть бути покликані приховати ці почуття, запевнити зовнішній світ у тому, що «тепер усе гаразд». Відомо, що це не лише єврейський досвід. У багатьох різних етнічних групах, які зазнали переслідування, жертви можуть відчувати, що їх якимось чином примушують дотримуватися «гідної» ролі, бути зразком для інших, першими прощати та заперечувати свою невпевненість. Однак вони можуть мати лише сміливість бути тими, ким вони є.

Також існує «героїчне рішення» проблеми сорому: наважуючись пишатися тим, що колись вважалося ганебним, люди намагаються відновити ті функції его, які були пошкоджені ганебним досвідом [11, с. 438458].

Головна терапевтична ідея полягає в тому, щоб уникнути спокуси ганьбити грандіозну людину перед соціальною групою, оскільки це призведе до посилення «грандіозного захисту». Коли покоління мають справу зі складнішим феноменом трансгенераційного сорому, найбільш доречне, що можна зробити, - це простежити залучені особисті історії.

Механізми, які можуть стимулювати передачу насильства між поколіннями, наразі детально формуються. Наприклад, ми знаємо, що батьки, які зазнавали надсильного насильства, часто мають суворий і караль- ний стиль батьківства. Мати з депресією або травмою набагато рідше налаштовується на спонукання дитини, такі як плач, воркування, жести, і, зрештою, посмішки, які мають на меті ініціювання відповідної реакції. Це було яскраво продемонстровано в експериментах із «нерухомим обличчям», коли виклики дитини стикалися 3 нульовою реакцією. Зрештою, зусилля ініціювати взаємодію з опікуном зменшувалися до такої міри, що могли навіть припинитися [12, с. 391].

Аналіз травматичних подій у минулому може надати поштовх до розв'язання проблеми трансгенераційної передачі в Україні [13, с. 90; 14, с. 4-5]. Негативний вплив травматичних подій має схожі патерни, однак у психіці конкретних людей він буде реалізований по-різному. Відомо, що робота з травмою охоплює три таких рівні: індивідуальний, колективний та культурний [15, с. 151]. Отже, робота з травмою також має проводитися на зазначених рівнях (табл. 1).

Наразі існує велика кількість підходів індивідуальної та групової терапії за трьома такими базовими напрямами: когнітивно-біхевіоріальним, гуманістичним та психодинамічним. Позитивний вплив можуть мати тілесно орієнтовані практики та арттерапія. Підвищення обізнаності стосовно своєї сімейної історії та історії своєї країни також має потенцію до пом'якшення негативних наслідків колективної травми.

На колективному рівні можуть використовуватися відповідні методи групової терапії, такі як психодрама, соціодрама, наративна терапія тощо. Щоб покласти край насильству від одного покоління до іншого, медичні працівники повинні визнати не тільки безпосередні наслідки травми, але і її довгострокові наслідки. На рівні системи охорони здоров'я це означає не лише зміцнення системи первинної медичної допомоги, а й розбудову служб психічного здоров'я, інформування про травми, а також забезпечення включення психічного здоров'я до первинного пакета послуг, доступних у постконфліктних умовах. На рівні сім'ї це передбачає спроможність вихователів дитини до забезпечення підтримки та піклування, які потрібні дітям для цілісного розвитку. Ця підтримка необхідна не лише в програмах раннього виховання дітей, а й у питаннях батьківства. Батьки, які постраждали від насильства, мають навчитися альтернативно проявляти агресію у вихованні дітей. Можливо, війна така ж стара, як і саме людство, однак передача насильства між поколіннями $є$ необов'язковою [16, с. 84-85].

На культурному рівні робота 3 травмою передбачає відтворення історичної правди - єдиного і позбавленого фрагмен- 
Потенційний вплив травматичних подій на наступні покоління

\begin{tabular}{|l|l|l|}
\hline \multicolumn{1}{|c|}{ травматична подія } & \multicolumn{1}{|c|}{ Фактори травматизації } & $\begin{array}{l}\text { Потенційний вплив на } \\
\text { наступні покоління }\end{array}$ \\
\hline Велика вітчизняна війна & наймасштабніша травма & $\begin{array}{l}\text { амбівалентність, } \\
\text { почуття провини }\end{array}$ \\
\hline екологічні катастрофи & $\begin{array}{l}\text { масштаб травми, нездатність емоційного } \\
\text { відреагування }\end{array}$ & $\begin{array}{l}\text { відчуття безпорадності } \\
\text { та страху }\end{array}$ \\
\hline $\begin{array}{l}\text { Чорнобильська } \\
\text { катастрофа }\end{array}$ & $\begin{array}{l}\text { неспроможність протистояти руйнівній дії } \\
\text { травми, нездатність емоційного відреагування }\end{array}$ & $\begin{array}{l}\text { відчуття безпорадності } \\
\text { та страху }\end{array}$ \\
\hline $\begin{array}{l}\text { колективізація, } \\
\text { розкуркулювання }\end{array}$ & $\begin{array}{l}\text { Масштаб травми, нездатність емоційного } \\
\text { відреагування }\end{array}$ & $\begin{array}{l}\text { відчуття провини та } \\
\text { сорому, самоінфляція }\end{array}$ \\
\hline репресії 30-40х років & $\begin{array}{l}\text { масштаб травми, несправедливість, } \\
\text { неспроможність протистояти руйнівній дії } \\
\text { травми }\end{array}$ & $\begin{array}{l}\text { амбівалентність, } \\
\text { почуття провини, } \\
\text { «героїчне рішення» }\end{array}$ \\
\hline $\begin{array}{l}\text { геноцид } \\
\text { (наприклад, Голокост) }\end{array}$ & $\begin{array}{l}\text { масштаб травми, несправедливість, } \\
\text { неспроможність протистояти руйнівній дії } \\
\text { травми }\end{array}$ & $\begin{array}{l}\text { бажання помсти, } \\
\text { відчуття сорому, } \\
\text { «героїчне рішення», } \\
\text { відчуття провини }\end{array}$ \\
\hline Голодомор & $\begin{array}{l}\text { масштаб травми, несправедливість, } \\
\text { неспроможність протистояти руйнівній дії } \\
\text { травми, нездатність емоційного відреагування }\end{array}$ & $\begin{array}{l}\text { амбівалентність, } \\
\text { бажання помсти, відчуття } \\
\text { безпорадності та провини }\end{array}$ \\
\hline
\end{tabular}

тарності наративу, що спрямований на зменшення рівня амбівалентності емоцій постраждалих. Також зазначимо, що дні жалоби та пам'ятні дати можуть бути корисними на деяких етапах переживання травми. Необхідними також $є$ відтворення єдиної національної ідентичності, набуття національної ідеї, відродження інтелектуальної еліти.

За результатами дослідження стає зрозумілою необхідність комплексного підходу до розв'язання питання трансгенераційноїпередачі травми в українському етносі. Залежно від фактора травматизації реакція наступних поколінь може варіюватися, однак більше схилятися до конкретних почуттів сорому, провини, амбівалентності, «героїчного рішення». Оскільки характер перенесених травматичних подій є різним (біологічно-демографічна, соціально-політична, культурна травми), а їхній вплив транслюється на три базових рівні (індивідуальний, колективний, культурний), процес «лікування» соціуму має бути комплексним та далекосяжним. Подальші дослідження в даній сфері будуть спрямовані на формування достатньої теоретичної бази для подальших практичних рухів. Між іншим, емпіричні дослідження трансгенераційної передачі в рамках родини можуть надати бажаного розвитку досліджуваній темі, хоча вони можуть стикнутись зі складністю інтерпретації.

\section{ЛITEPATУPA:}

1. Fischer G., Riedesser L. Lehrbuch der Psychotraumatologie. München : Ernst Reinhard. 1998. C. 145-147.

2. The transgenerational transmission of traumatic experiences of the Second World War over three generations - a psychoanalytical perspective. URL: https://europepmc.org/article/med/23155786 (дата звернення: 20.11.2021).

3. Collective Trauma and the Social Construction of Meaning. URL: https://www.ncbi.nlm.nih.gov/pmc/ articles/PMC6095989/ (дата звернення: 22.11.2021).

4. Kogan I. The cry of mute children. Apsychoanalytic perspective of the second generation of the Holocaust. Free Association Books, London, New York. Dt: (1998). Der stumme Schreider Kinder. Die zweite Generation der Holocaust-Opfer. Frankfurt a. M. : Fischer. 2002. C. 148-150.

5. Grubrich-Simitis I. From concretism to metaphor. Psychoanalytic Study of the Child. 1984. № 39. C. 301-309.

6. Faimberg $\mathrm{H}$. The telescoping of generations. London : Routledge. 2005. P. 23-27.

7. Volkan V. The Third Reich in the unconscious. New York : Brunner. 2002. P. 13-15.

8. Cultural Trauma: The Other Face of Social Change. URL: https://journals.sagepub.com/doi/ 10.1177/136843100003004004 (дата звернення: 22.11.2021).

9. Memorial candles: Children of the Holocaust. URL: $\quad$ https://psycnet.apa.org/record/1992-98003-000 (дата звернення: 22.11.2021).

10. The analysis of the self: A systematic approach to the psychoanalytic treatment of narcissistic personality disorders. URL: https://psycnet.apa.org/ record/2009-16139-000 (дата звернення: 22.11.2021).

11. De Mendelssohn F. The aesthetics of the political in group analytic process: The wider scope. Group Analysis. 2000. № 33. C. 438-458.

12. Transgenerational Transmission of Trauma: Guilt, Shame, and the "Heroic Dilemma". URL: https:// guilfordjournals.com/doi/abs/10.1521/ijgp.2008.58.3.38 9?journalCode=ijgp (дата звернення: 21.11.2021).

13. Колективна травма та групова ідентичність. URL: http://gorn.kiev.ua/Gorn2012-3.pdf (дата звернення: 22.11.2021). 


\section{ГАБІТУС}

14. Історична травма спільноти. Як нащадкам пам'ятати трагічне? URL: https://lib.iitta.gov.ua/ 707323/1/NaydonovaLA_st_2011_2.pdf (дата звернення: 22.11.2021).

15. Історична травма Голодомору. Проблема, гіпотеза та методологія дослідження. URL: http:// www.irbis-nbuv.gov.ua/cgi-bin/irbis nbuv/ cgiirbis_64.exe?I21DBN=LINK\&P21DBN=UJRN\&
$Z 21 I D=\& S 21 R E F=10 \& S 21 C N R=20 \& S 21 S T N=1 \& S$ $21 \mathrm{FMT}=\mathrm{ASP}$ meta $\& \mathrm{C} 21 \mathrm{COM}=\mathrm{S} \& 2 \quad \mathrm{~S} 21 \mathrm{P} 03=\mathrm{FILA}$ =\&2_S21STR=Ntip_2013_6_16 (дата звернення: 22.11.2021).

16. Травмататравмотерапія:історіятасьогодення. URL: https://uvnpn.com.ua/arkhiv- nomeriv/2018/tom26-vipusk-4-97/travma-ta-travmaterap-ya-stor-ya-tasogodennya (дата звернення: 22.11.2021). 